\title{
Influence of the spatial resolution of satellite-derived vegetation parameters on the biogenic Volatile Organic Compounds (VOC) emission modeling
}

GEOINFORMATION CONFERENCE

\author{
Carlos M.S. Silveira ${ }^{1}$, Oxana A. Tchepel ${ }^{2 *}$ \\ 1 CESAM \& Department of Environment and Planning, \\ University of Aveiro, Aveiro, 3810-193 Aveiro, Portugal \\ 2 Faculty of Sciences and Technology, University of Coimbra, \\ Rua Luis Reis Santos, Polo II, 3070-788 Coimbra, Portugal
}

Received 05 August 2013; accepted 15 February 2014

\begin{abstract}
Vegetation is a natural source of Volatile Organic Compounds (VOC) that plays an important role in atmospheric chemistry. The main objective of the current study is to implement a model to quantify process-based VOC emissions from plants that focuses on the relationship between the sensitivity of VOC emission estimates to spatial resolution data, based on scientific knowledge and vegetation dynamics derived from satellite observations. The Normalized Difference Vegetation Index (NDVI) and Leaf Area Index (LAI) were elected to examine this issue using different resolutions of satellite-derived products: $22 \mathrm{~m}$ from the DEIMOS-1 satellite, and 250m and $1000 \mathrm{~m}$ provided by MODIS. The study is focused on an area of $80 \times 80 \mathrm{~km}^{2}$ in Portugal for 2011 . Detailed land cover and meteorological data are also included in the emission quantification algorithm. The primary outcomes were determined using a multi-scale analysis showing spatial and temporal variations in the vegetation parameters and modeling results. The results confirm that the emissions model is highly sensitive to the spatial resolution of the satellite-derived data, resulting in about a $30 \%$ difference in total isoprene emissions for the study area.
\end{abstract}

Keywords: NDVI $\cdot$ LAl • Biogenic emissions • Volatile Organic Compounds • Spatial resolution

(C) Versita Sp. z o.o.

\section{Introduction}

Volatile organic compounds (VOC) play an important role in atmospheric chemistry, contributing to tropospheric ozone and secondary organic aerosol formation [1-3]. On the global scale, vegetation generates over $90 \%$ of VOC emissions [4] of which isoprene is emphasized as the most

*E-mail: oxana@uc.pt abundant and highly reactive $[5,6]$. However, direct measurements of VOC emissions are still scarce or absent for most ecosystems and vegetation types. In response, modeling approaches able to quantify biogenic VOC emissions and to characterize their spatial and temporal variations have been developed, from leaf-level $[7,8]$ to global scale models [9]. In addition, satellite observations are increasingly being used in combination with tropospheric chemistry transport models to constrain isoprene emission inventories, through top-down inversion approaches $[10,11]$. Emission rates of biogenic VOC depend on the in- 
teraction between environmental, biological, physical and chemical processes. Quantifying the emissions for each type of vegetation may be achieved by using the definition of the specific emission capacity of each type under standardized conditions (standard temperature and light) and then correcting for the actual environmental conditions. Vegetation parameters and their dynamics will also be considered since they play an important role in emissions modeling. For this purpose satellite-derived parameters,such as the Normalized Difference Vegetation Index (NDVI) and Leaf Area Index (LAI), are particularly useful for estimating $\mathrm{VOC}$ emissions, the spatial resolution of the satellite data may affect the results yielded from biogenic VOC modeling.

An understanding of scaling effects is critical for the proper interpretation of remote sensing data gathered at different temporal and spatial scales $[12,13]$. Several approaches could be implemented to study the effects of using satellite images with fine and course data resolutions from different sensors and those with course data resolutions constructed from compiling fine resolution data $[14,15]$. Independent of how the scale was derived or the degree of coarseness of data resolution, the comparison and integration of multi-scale data analysis is a challenging issue. The main objective of this study is to use a model to quantify process-based VOC emissions from plants while paying special attention to the effects of different spatial resolutions on VOC emission estimates using scientific knowledge and vegetation dynamics derived from satellite observations. To address the issue of the impact of spatial and temporal variability on VOC emission estimates ", the data resolution of satellite-derived LAI and NDVI on isoprene emissions will be examined with the resulting VOC emission values. In addition, the influence of the different assumptions made when entering the data are considered in the modeling approach of the final emissions inventory. The methodology is applied to a selected area of $80 \times 80 \mathrm{~km}^{2}$ located in Portugal.

\section{Material and methods}

\subsection{Satellite data}

Satellite observations are compiled and processed to provide crucial information for the biogenic emissions modeling. This study uses vegetation parameters from the Moderate Resolution Imaging Spectroradiometer (MODIS) and DEIMOS-1 satellites. Leaf Area Index (LAI) and Normalized Differentiating Vegetation Index (NDVI) values are analyzed at different resolutions.

DEIMOS-1 data, commercially available, were obtained from a three-band multispectral image system and have a 22-m spatial resolution at a nominal altitude $(663 \mathrm{~km})$ and with $620 \mathrm{~km}$ swath. Data are delivered in three spectral bands: Near-Infrared, Red, and Green. Radiometric calibration and orthorectification with ground control points defined manually were applied to process the DEIMOS-1 raw data.

The MODIS data with 1000-m resolution were obtained from publicly available products (MOD15 and MOD13, available at http://lpdaac.usgs.gov/get data). Addition data used in the multiscale analysis included self-processed data with 250-m resolution, specifically the MODIS spectral bands 1 and 2, RED and NIR spectral regions respectively. The general specifications of the products used in this work are summarized in Table 1.

Since the access to DEIMOS-1 products (NDVI, LAI) is not publicly available, only three days of data were considered in this study. However, the images used were carefully selected based on their quality, the seasonality of the vegetation parameters, and the effects of both of these parameters on the methodology used to estimate VOC emissions. The primary concern was the impact of spatial variability on emission values derived from models using data with differing resolutions of of satellite-derived vegetation parameters. In addition, this study will contribute to the limited body of knowledge currently published regarding satellite-derived vegetation parameters. MODIS products with $1000 \mathrm{~m}$ resolution were obtained from http://lpdaac.usgs.gov/get data. In addition, d selfprocessed data with a $250 \mathrm{~m}$ were utilized in the multiscalar aspect of this study include.

NDVI measures the vegetation reflectance and absorption over different wavelengths and is widely used to monitor vegetation conditions. Thus, the NDVI is calculated as the difference between near-infrared (NIR) and Red spectral reflectances obtained from a multispectral image:

$$
N D V I=(\rho N I R-\rho R E D) /(\rho N I R+\rho R E D)
$$

Subsequently, LAI values are retrieved from the NDVI values using the Back Up Algorithm [17]. Daily NDVI values provided from DEIMOS-1 and the Maximum Value Composite of NDVI values for eight days from MODIS imagery were used in the analysis (Table 1).

LAI defines an important structural property of the plant canopy, namely the leaf area per unit ground area. In addition to NDVI values, the biome classification is also required to determine the $\mathrm{LAI}$. The biome classification for each pixel in the study area (Figure 1) is based on information obtained from the Corine Land Cover (CLC) database.

The following correspondence between CLC classification and the biomes for LAl estimation was used:

Biome 1: Grasses and Cereal Crops (Arable Lands, Pas- 
Table 1. Information about the satellite-derived products used in this study.

\begin{tabular}{|c|c|c|}
\hline & DEIMOS - 1 & MODIS \\
\hline $\begin{array}{l}\text { Spectral bands } \\
\text { considered in this work }\end{array}$ & $\begin{array}{l}\text { Red: 630-690nm } \\
\text { NIR:770-900 nm }\end{array}$ & $\begin{array}{l}\text { Red (band1):620-670 nm } \\
\text { NIR (band2): } 841-876 \mathrm{~nm}\end{array}$ \\
\hline Dates & $\begin{array}{l}3 \text { March } \\
9 \text { May } \\
23 \text { July }\end{array}$ & $\begin{array}{l}27 \text { February - } 6 \text { March } \\
2 \text { May-9May } \\
20 \text { July - } 27 \text { July }\end{array}$ \\
\hline NDVI & $\begin{array}{l}\text {-self procesed product } \\
\text { form Red and NIR bands } \\
-22 \mathrm{~m} \text { spatial resolution } \\
\text { - no atmospheric correction }\end{array}$ & $\begin{array}{l}\text { 1)NDVI 250m resolution: } \\
\text {-self processed data from } \\
\text { band1 and band2 } \\
\text {-no atmospheric correction } \\
\text {-Maximum Value } \\
\text { Composite } \\
\text { 2) NDVI } 1000 \mathrm{~m} \text { resolution } \\
\text { - MOD13 publicly available } \\
\text { product }\end{array}$ \\
\hline LAI & $\begin{array}{l}\text {-retrived from NDVI and } \\
\text { biome classification based } \\
\text { on CORINE Land Cover } \\
\text { data } \\
\text {-22m resolution }\end{array}$ & $\begin{array}{l}\text { 1)LAI 250m resolution: } \\
\text {-self processed data from } \\
\text { NDVI product and biome } \\
\text { classification based on } \\
\text { CORINE } \\
\text { 2) LAI } 1000 \text { m resolution: } \\
\text {-MOD15 publicly available } \\
\text { product }\end{array}$ \\
\hline
\end{tabular}

tures, Heterogeneous agricultural areas, Agro-forestry areas).

Biome 2: Shrubs (Land principally occupied by agriculture with significant areas of natural vegetation, Natural grasslands, Moors and Heath-land, Sclerophyllous vegetation, Transitional woodland-shrub).

Biome 5: Broadleaf Forest (Broad-leaved forest, Mixed forest).

Biome 6: Needle Forest (Coniferous forest).

Biomes 3 and 4 considered in the Back Up algorithm are not presented in the study area.

\subsection{Biogenic emissions}

VOC released into the atmosphere by processes other than human activities have been studied because of their contribution to atmospheric chemistry. Among the biogenic VOC, isoprene and monoterpenes are some of the most reactive and play a significant and, often dominant. role in ozone formation.

The approach currently used to estimate biogenic VOC emissions integrates a simple conceptual model with GIS databases. The conceptual model was adopted from several authors 4, 9, 18, 19 and based on empirical algorithms. The dependence of VOC emissions on photosyn- thetically active radiation (PAR), ambient air temperature, and vegetation parameters are taken into account as following:

$$
E=\varepsilon \times M_{a} \times \gamma_{L} \times \gamma_{T} \times \gamma_{L A I} \times \gamma_{N D V I}
$$

where:

$\mathrm{E}$ - Net emission of a compound $\left[\mu \mathrm{g} \cdot \mathrm{m}^{-2} \cdot \mathrm{h}^{-1}\right]$

$\varepsilon$ - Emission factor at standard conditions $\left(T=30^{\circ} \mathrm{C}\right.$, $\left.\mathrm{PAR}=1000 \mu \mathrm{mol} . \mathrm{m}^{-2} \cdot \mathrm{s}^{-1}\right)\left[\mu \mathrm{g} \cdot \mathrm{g}^{-1} \cdot \mathrm{h}^{-1}\right]$

MA - Dry leaves mass per area unit $\left[\mathrm{g} \cdot \mathrm{m}^{-2}\right]$

$\gamma_{L}-$ Light correction factor

$\gamma_{T}$ - Temperature correction factor

$\gamma_{L A I}-\mathrm{LAl}$ correction factor

$\gamma_{N D V I}-\mathrm{NDVI}$ correction factor

A compilation of VOC emission factors adapted for Portugal was applied. Within the study area, isoprene emissions are attributed to eucalyptus trees with an emission rate of $70 \mu \mathrm{g}$ of isoprene per $\mathrm{g}$ of biomass per hour at $\mathrm{T}=30^{\circ} \mathrm{C}$ and $\mathrm{PAR}=1000 \mu \mathrm{mol} \cdot \mathrm{m}^{-2} \cdot \mathrm{s}^{-1}$.

Isoprene is emitted in the presence of sunlight and increases exponentially with temperature, with maximum emissions occurring near of $40^{\circ} \mathrm{C}$. The Weather Research and Forecasting (WRF) model was applied to characterize 




$$
\begin{aligned}
& \gamma_{T}= {\left[\exp \left(C_{T 1} \times\left(T_{L}-T_{S}\right)\right) /\left(R \times T_{S} \times T_{L}\right)\right] } \\
& /\left[C_{T 3}+\exp \left(\left(C_{T 2} \times\left(T_{L}-T_{m}\right)\right) /\left(R \times T_{S} \times T_{L}\right)\right)\right]
\end{aligned}
$$

where:

$\mathrm{T}_{L}$ - Absolute leaf temperature $[\mathrm{K}]$

$\mathrm{T}_{S}$ - Leaf temperature at standard conditions (typically $303.16 \mathrm{~K}$ )

$\mathrm{T}_{m}=314 \mathrm{~K}$

$\mathrm{R}-8.314 \mathrm{~J} \cdot \mathrm{mol}^{-1} \cdot \mathrm{K}^{-1}$ (gas constant)

$\mathrm{C}_{T 1}=95000 \mathrm{~J} \cdot \mathrm{mol}-1$

$\mathrm{C}_{T 2}=230000 \mathrm{~J} \cdot \mathrm{mol}-1$

$\mathrm{C}_{T 3}=0.961$

LAI is used to characterize seasonal variations in the amount of foliage at a given location. Using the methodology described in [9], the LAl correction factor is implemented:

$$
\gamma_{L A I}=(0.49 \times L A I) /\left[\left(1+0.2 \times L A I^{2}\right)^{0.5}\right]
$$

NDVI is employed as an indicator of the foliar greenness. Multilayer analysis of the NDVI may provide additional information on plant conditions, such as drought stress [21]. In the current study, multilayer analysis of NDVI was implemented to determine the correction factor for isoprene emission quantification using a pixel-actual value for the current image and its multiyear absolute maximum value as following:

$$
\gamma_{N D V I}=N D V I_{a c t} / N D V I_{\max }
$$

In order to provide greater flexibility in handling and analysis of input and output data, the biogenic emission model was implemented as an application in Geographic Information System (GIS). Python programming language was used in combination with a model builder within the ArcGIS framework. A general concept of the modeling system is presented in Figure 2.

\section{Results}

The methodology described above was applied to the study area to quantify biogenic isoprene emissions. The data are analyzed for spatial and temporal variation of satellite-derived vegetation parametersand for the degree to which emission values are sensitive to different spatial resolutions. To accomplish this, the data were processed with three spatial resolutions $(22 \mathrm{~m}, 250 \mathrm{~m}$ and 




Figure 2. A general concept of the modeling system used to determine biogenic VOC.

$1000 \mathrm{~m})$ for three selected dates from 2011 (Table 1), hereafter identified by the months. Figure 3 shows the seasonal variation of the NDVI for DEIMOS-1 images (22m resolution).

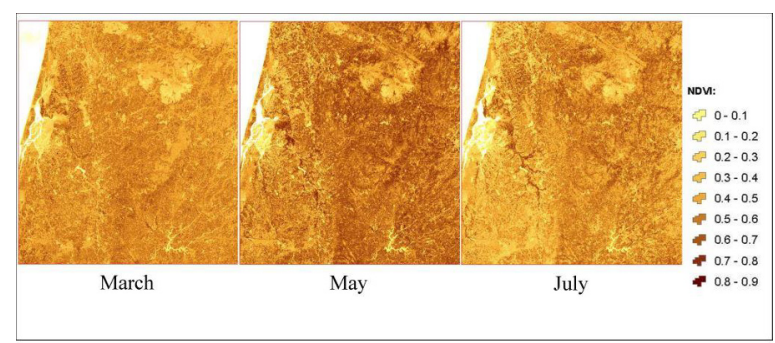

Figure 3. Spatial variation of the NDVI obtained from DEIMOS-1 images for the three selected dates.

The LAI product recovered with different resolutions is presented in Figure 4, focusing on a randomly selected area within the study domain as an example. It should be highlighted that MODIS data with $250 \mathrm{~m}$ and $1000 \mathrm{~m}$ resolution are obtained from 8- and 16-day composite values, respectively, while DEIMOS-22m data are based on a single NDVI value per day for each pixel.

As could be seen in Figure 4, coarse resolution data exhibit, in general, larger areas with and yield the highest LAl values. This analysis is enhanced by the boxplot presented in Figure 5, showing that the 95th -percentile of the $\mathrm{LAI}$ increases when the data resolution is decreasing. However, the trend on LAI and NDVI data is much more complex when different quantiles are analyzed. It should be stressed that $250 \mathrm{~m}$ and $1000 \mathrm{~m}$ data are derived from

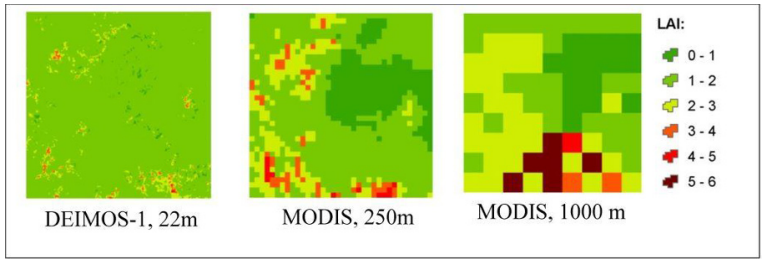

Figure 4. Satellite-derived LAI with different spatial resolutions for a randomly selected area of $9 \times 9 \mathrm{~km}^{2}$ within the study domain for July 2011

composite maximum values and $22 \mathrm{~m}$ values are obtained from a single image. Additionally data for $1000 \mathrm{~m}$ are obtained from the standard MODIS product based on a different database of biome classifications, while $22 \mathrm{~m}$ and $250 \mathrm{~m}$ products are based on the same CLC data. Moreover, an atmospheric correction was not applied to selfderived products (data with $22 \mathrm{~m}$ and $250 \mathrm{~m}$ resolution). As discussed before, isoprene emissions within the study area are attributed to eucalyptus only. Therefore, in addition to CLC classes, forest inventory with spatial distribution of tree species was also considered. Thus, eucalyptus areas are distinguished within broad-leaved and mixed forests. LAI variability for the pixels classified as eucalyptus forest that were examined for isoprene emission quantification is presented in Figure 5. Both parameters, NDVI and LAI calculated for evergreen eucalyptus exhibit seasonal variations (Figures 5 and 6). Several factors may have influenced this behavior, including stress conditions such as drought incurred during the summer months and the influence of the understory vegetation.

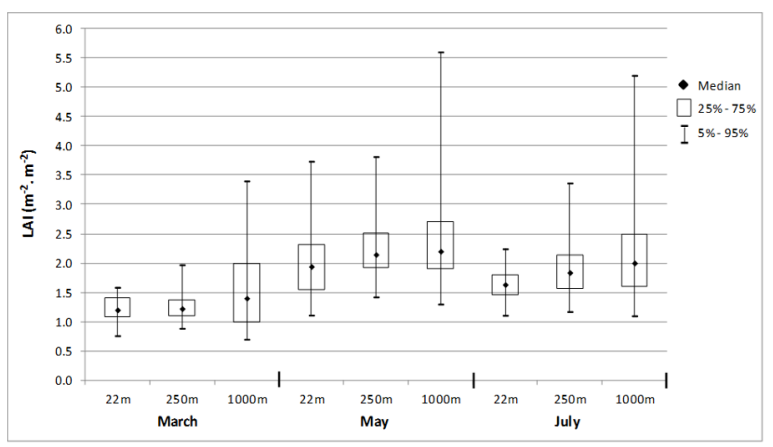

Figure 5. Seasonal variation of the LAl used for isoprene emissions quantification. (Dates for the satellite images considered in the analysis are referred in Table 1).

Biogenic VOC emissions depend not only on vegetation parameters, but also on environmental conditions. As was mentioned above, isoprene emissions increase exponentially with temperature until about $40^{\circ} \mathrm{C}$. Atmospheric temperature varied widely in the study area during the 


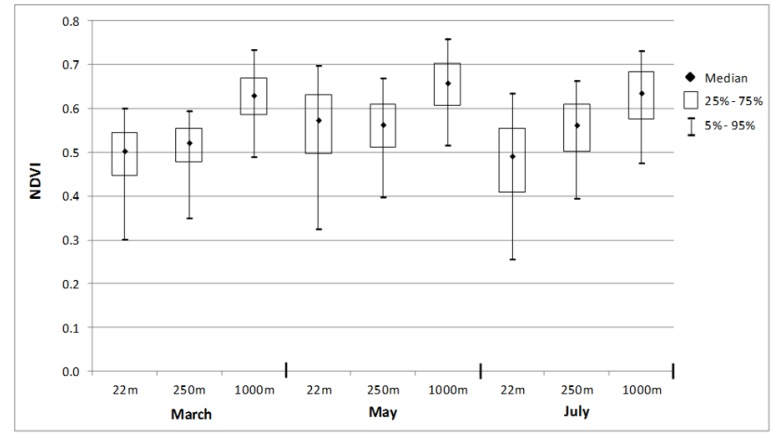

Figure 6. Seasonal variation of the NDVI used for isoprene emissions quantification. (Dates for the satellite images considered in the analysis are referred in Table 1).

selected days. On March 3, the daily average temperature was $10^{\circ} \mathrm{C}$, ranging $5^{\circ} \mathrm{C}$ to $13^{\circ} \mathrm{C}$. During the other dates, the temperature varied by a similar amount, with average temperature of $24 ?^{\circ} \mathrm{C}$ and minimum and maximum values of $16^{\circ} \mathrm{C}$ and $27^{\circ} \mathrm{C}$, respectively. The spatial variability of the temperature is more conservative than was observed for vegetation parameters within the study area of $80 \times 80 \mathrm{~km}^{2}$. Nevertheless, the proximity to the Atlantic Ocean and presence of mountains define the surface temperature field simulated by the meteorological model. Final results for the isoprene emissions are presented in Figure 7 as the emission rate in $\mu \mathrm{g} \cdot \mathrm{m}^{-2} \cdot \mathrm{h}^{-1}$ for different seasons and different spatial resolutions of the input data. Table 2 depicts the total isoprene emission for the same dates in the context of the entire domain.

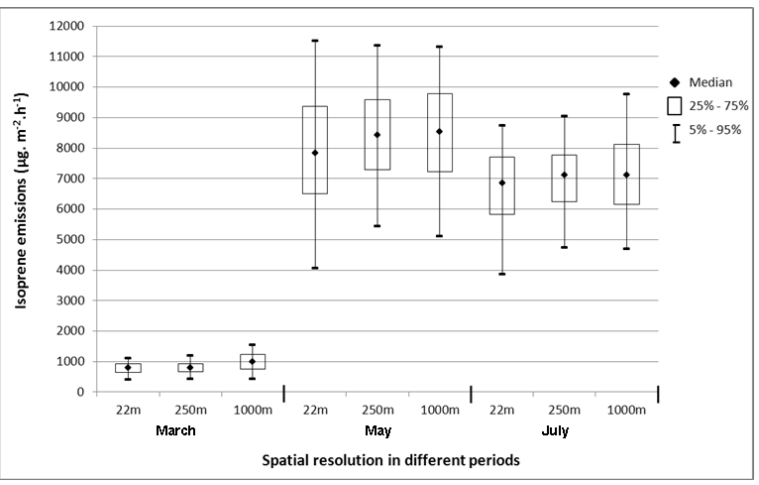

Figure 7. Isoprene emission rate (i'.g.m $\left.\mathrm{m}^{-2} \cdot \mathrm{h}^{-1}\right)$ for different seasons with different spatial data resolution.

Isoprene emissions reveal strong seasonal variations, as presented in Figure 7. These variations are primary related to seasonal differences in air temperature. However, the LAI and NDVI spatial resolutions used as inputs for the emissions modeling are also important to consider
Table 2. Total isoprene emission $(\mathrm{kg})$ for the study area for $12 \mathrm{~h}$ of the selected days, utilizing different spatial resolutions of input data.

\begin{tabular}{c|ccc}
\hline \multirow{2}{*}{ Date } & \multicolumn{3}{|c}{ Spatial } \\
& resolution \\
& $22 \mathrm{~m}$ & $250 \mathrm{~m}$ & $1000 \mathrm{~m}$ \\
\hline March & 864 & 882 & 1376 \\
\hline May & 8711 & 9227 & 9879 \\
\hline July & 7369 & 7736 & 9879 \\
\hline
\end{tabular}

when describing the emissions variability for each date.

The discrepancy between the emission estimates with different resolutions is more evident when the total emission values for the domain are analyzed (Table 2). For example, the highest isoprene emissions are obtained with lower resolution satellite data, resulting in average about $30 \%$ higher than the total emissions. It is important to stress that the sensitivity to LAI and NDVI resolution is highlighted in this work. However, an additional source of uncertainty in $\mathrm{VOC}$ emission modeling related to the model itself and the input data is also recognized. Moreover, the uncertainties assessment and the reliability of emission inventories depends on the quality of the criteria defined by the user of the inventory [22]. The modelling approach used in this work to estimate biogenic emissions is based primarily on Guenther formulations [4, 9]. This methodology has been widely validated in the literature $[4,9,18,19]$, showing that isoprene emission estimates are within a factor of 2 of the above-canopy emission fluxes measured. In general, these uncertainties may be related to several factors: calculation algorithms, processing, data quality, resolution and disaggregation/aggregation methods $[14,18,22]$. Among the described throughout this study, emphasis is placed on the spatial resolution of the input data used to estimate biogenic emissions. In addition to the analyzing the degree of sensitivity, the model was also adjusted for the level of land cover. This was accomplished by using a land-use spatial database with tree species distribution and new emission factors adapted to the current environmental conditions, which contrasted with broader land-cover classifications commonly considered in biogenic emission inventories. For example, a forest classified as broad-leaved without further identification of tree species, will result in the wrong selection of the emission factors and, therefore, increase the uncertainty of the final emission estimates. The information on trees species was obtained by combining CLC classes with the forest inventory. 


\section{Conclusions}

A multi-scale analysis of satellite-derived vegetation parameters is presented in this work focusing on their importance for biogenic VOC emission modeling. The data on NDVI and LAI with $22 \mathrm{~m}, 250 \mathrm{~m}$ and $1000 \mathrm{~m}$ resolution obtained from DEIMOS-1 and MODIS are analyzed. There is good agreement between average values from the analyzed dataset, but the quantile analysis revealed important differences in the data distribution. The low resolution data analyzed as maximum composite values present significantly higher values of LAI when compared to a single value from a high resolution image. Differences found in the multi-scale datasets of LAI and NDVI affect the isoprene emissions varying by about $30 \%$ within the study area. Analysis of additional parameters and quantification of the overall uncertainty related to the input data (e.g. resolution, processing) in VOC emission modeling should be implemented and explored in future research.

\section{Acknowledgements}

The Portuguese Ministry of Science, Technology and Higher Education is acknowledged for the financial support of the project EMOSAT (PTDC/CTEATM/103253/2008, FCOMP-01-0124-FEDER-009305).

\section{References}

[1] Griffin R.J., Cocker D.R., Seinfeld J.H., Dabdub D., Estimate of global atmospheric organic aerosol from oxidation of biogenic hydrocarbons. Geophys. Res. Lett., 1999, 26, 2721-2724, DOI: 10.1029/1999GL900476

[2] Kanakidou M., Seinfeld J.H., Pandis S.N., Barnes I., Dentener F.J., Facchini M.C., et al., Organic aerosol and global climate modelling: a review. Atmos. Chem. Phys., 2005, 5, 1053-1123, DOI: 10.5194/acp-51053-2005

[3] Curci G., Beekmann M., Vautard R., Smiatek G., Steinbrecher R., Theloke J., et al., Modelling study of the impact of isoprene and terpene biogenic emissions on European ozone levels. Atmos. Environ., 2009, 43(7), 1444-1455, DOI: 10.1016/j.atmosenv.2008.02.070

[4] Guenther A., Hewitt C.N., Erickson D., Fall R., Geron C., Graedel T., et al., A global model of natural volatile organic compound emissions. J. Geophys. Res-Atmos., 1995, 100 (D5), 8873-8892, DOI: 10.1029/94JD02950

[5] Pacifico F., Harrison S.P., Jones C.D., Sitch
S., Isoprene emissions and climate (review). Atmos. Environ., 2009, 43, 6121-6135, DOI 10.1016/j.atmosenv.2009.09.002

[6] Arneth A., Niinemets ï'., Pressley S., Bï'ck J., Hari P., Karl T., et al., Process-based estimates of terrestrial ecosystem isoprene emissions: incorporating the effects of a direct CO2-isoprene interaction. Atmos. Chem. Phys., 2007, 7, 31-53, DOI: 10.5194/acp-731-2007

[7] Wilkinson M.J., Monson R.K., Trahan N., Lee S., Brown E., Jackson R.B., et al., Leaf isoprene emission rate as a function of atmospheric $\mathrm{CO} 2$ concentration. Gilob. Change Biol., 2009, 15, 1189-1200, DOI: 10.1111/j.1365-2486.2008.01803.x

[8] Niinemets i'‘., Tenhunen J.D., Harley P.C., Steinbrecher R., A model of isoprene emission based on energetic requirements for isoprene synthesis and leaf photosynthetic properties for Liquidambar and Quercus. Plant Cell Environ., 1999, 22, 1319-1335, DOI: 10.1046/j.1365-3040.1999.00505.x

[9] Guenther A., Karl T., Harley P., Wiedinmyer C., Palmer P.I., Geron C., Estimates of global terrestrial isoprene emissions using MEGAN (Model of Emissions of Gases and Aerosols from Nature). Atmos. Chem. Phys., 2006, 6, 3181-3210, DOI: 10.5194/acp6-3181-2006

[10] Palmer P.I., Jacob D.J., Fiore A.M., Martin R.V., Chance K., Kurosu T.P., Mapping isoprene emissions over North America using formaldehyde column observations from space. J. Geophys. Res-Atmos., 2003, 108 (D6), 27, DOI: 10.1029/2002JD002153

[11] Abbot D.S., Palmer P.I., Martin R.V., Chance K.V., Jacob D.J., Guenther A., Seasonal and interannual variability of North American isoprene emissions as determined by formaldehyde column measurements from space. Geophys. Res. Lett., 2003, 30 (17), 4 pp, DOI: 10.1029/2003GL017336

[12] Cheng Y., Gamon J.A., Fuentes D.A., Mao Z., Sims D.A., Qiu H., et al., A multi-scale analysis of dynamic optical signals in a Southern California chaparral ecosystem: A comparison of field, AVIRIS and MODIS data. Remote Sens. Environ., 2006, 103, 369378, DOI: 10.1016/j.rse.2005.06.013

[13] Tarnavsky E., Garrigues S., Brown M.E., Multiscale geostatistical analysis of AVHRR, SPOTVGT, and MODIS global NDVI products. Remote Sens. Environ., 2008, 112 (2), 535-549, DOI: 10.1016/j.rse.2007.05.008

[14] Tian Y., Woodcock C.E., Wang Y., Privette J.L., Shabanov N.V., Zhou L., et al., Multiscale analysis and validation of the MODIS LAI product. I. Uncertainty assessment. Remote Sens. Environ., 2002, 83, 414- 
430, DOI: 10.1016/S0034-4257(02)00047-0

[15] Garrigues S., Lacaze R., Baret F., Morisette J.T., Weiss M., Nickeson J.E., et al., Validation and intercomparison of global Leaf Area Index products derived from remote sensing data. J. Geophys. Res-Biogeo., 2008, 113 (G2), 20 pp., DOI: 10.1029/2007JG000635

[16] Kim J., Guo Q., Baldocchi D.D., Leclerc M.Y., Xu L., Schmid H.P., Upscaling fluxes from tower to landscape: Overlaying flux footprints on highresolution (IKONOS) images of vegetation cover. Agr. Forest Meteorol., 2006, 136, 132-146, DOI: 10.1016/j.agrformet.2004.11.015

[17] Knyazikhin Y., Glassy J., Privette J.L., Tian Y., Lotsch A., Zhang Y., et al., MODIS Leaf Area Index (LAI) and Fraction of Photosynthetically Active Radiation Absorbed by Vegetation (FPAR) Product. (MOD15). Algorithm Theoretical Basis Document, 1999, 126 pp.

[18] Simpson D., Guenther A., Hewitt C.N., Steinbrecher R., Biogenic emissions in Europe: 1. Estimates and uncertainties. J. Geophys. Res-Atmos., 1995, 100(D11), 22875-22890, DOI: 10.1029/95JD02368
[19] Oderbolz D.C., Aksoyoglu S., Keller J., Barmpadimos I., Steinbrecher R., Skj?th C.A., et al., A comprehensive emission inventory of biogenic volatile organic compounds in Europe: improved seasonality and land-cover. Atmos. Chem. Phys., 2013, 13, 16891712, DOI: 10.5194/acp-13-1689-2013

[20] Skamarock W.C., Klemp J.B., Dudhia J., Gill D.O., Barker D.M., Duda M., Huang X-Y., Wang W., Powers J.G., A Description of the Advanced Research WRF Version 3. NCAR Technical Note, 2008, 113 pp., DOI: 10.5065/D68S4MVH

[21] Kogan F., Global Drought Watch from Space. B. Am. Meteorol. Soc., 1997, 78 (4), 621-636, DOI: 10.1175/15200477(1997)078;0621:GDWFS;2.0.CO;2

[22] Aardenne J.v., Pulles, T., Uncertainty in emission inventories: What do we mean and how could we assess it? 11th International Emission Inventory Conference - "Emission Inventories - Partnering for the Future", April 15-18, 2002, Atlanta, GA. 